\title{
The Brazilian Business World: The difficult adaptation to Globalization
}

\author{
Empresas brasileiras: a difícil adaptação à globalização
}

VIRGÍLIO CAIXETA ARRAES*

Rev. Bras. Polít. Int. 53 (2): 198-216 [2010]

\section{Introduction}

The internationalization of production is when citizens of a certain country have access to goods and services of foreign origin. There are three ways that this situation can occur: commerce, Foreign Direct Investment (FDI), and contractual relationships.

Foreign Direct Investment is characterized by the movement of a legally registered body (e.g. a business or corporation) - beyond its customary frontier in order to perform an activity through which that body can exercise the total or partial control of a productive unit - branch, subsidiary or joint venture.

The need for a commercial presence via FDI is not always required for internationalization to occur due to the segmentation of specific services such as engineering or medicine. In these two examples, there occurs a temporary transposition of highly qualified labor.

Another example of internationalization can be highlighted by means of consumer intermediaries, such as in the tourism, education and health sectors. Likewise, it is possible to consolidate the business activity of producers and consumers in different markets originating from two locations. A hypothetical example would be when a British tourist is lodged at a hotel belonging to a French chain in Brazilian territory (Gonçalves 2002, 24-5).

With the end of the Cold War, the 1990s saw the elimination of most of the practices utilized by countries to limit the presence of foreign capital, irrespective of the means - portfolio or foreign direct investment.

In the case of peripheral or developing countries, the justification for the validity of a specific degree of protectionism within its legal regulations was to stimulate the generation and development of endogenous technology.

The main objective was to gradually replace industrial imports, an important step that was considered essential to overcome underdevelopment, in accordance

* Associate Professor in the Department of History of the University of Brasília (arraes@unb.br). 
with the existing beliefs at that time expressed by the Economic Commission for Latin America and the Caribbean (ECLAC) and to reduce extreme social inequality.

In the last decade of the 20th century, international organizations such as the World Bank (WB) and the Inter-American Development Bank (IDB) began to develop a response that was very different from the thinking of ECLAC and which would severely affect the role of the State in the promotion of a more egalitarian form of growth from a social point of view.

Among numerous recommended measures, the need became apparent to structure a very different institutional environment from the existing one or from that of national developmentalism as found in parts of Latin America and in social-democratic countries in Europe.

It was felt that the Brazilian State should alter its practices of intervening in the productive sector and should thereby restrict its administration to the provision of health services, education and basic infrastructure. Thus, governments should privatize their corporations or provide concessions for the exploitation of specific services, even in the cases of natural monopolies such as the water and energy sectors, for instance.

The State should also concurrently modify tax laws, and even go so far as modify constitutional legislation if necessary. The objectives of these modifications would be to attract more FDI, reinforce the right to property, ensure the permanence of specific contracts (especially those established with global organizations like the International Monetary Fund (IMF) and financial institutions like creditor banks), consolidate fiscal discipline and establish the liberalization of basic interest and exchange rates.

Thus, these recommendations made up the ideology of liberal-developmentalism and took precedence over the idea that the international system was composed of countries at different stages of development.

As a consequence of the supposed universality of such procedures, their definitive adoption would lead to bringing about effects in various countries that would be manifested in countless forms of instability: political, economic and even cultural.

The economic crises between 1994 and 2002 initially had global dimensions in Mexico, Russia, Asia (Singapore, Hong Kong, Taiwan, and South Korea), etc. until they arrived in Argentina and Brazil.

Despite the undeniable record of negative side-effects of liberal developmentalism in Latin America, there was no program structure available that could oppose it in a long-term and consistent manner.

\section{Brazil: the transformation}

The first neoliberal reforms were implemented undramatically in Brazil at the beginning of the term of office of President Jose Sarney (1985-1990), who 
belonged to the Brazilian Democratic Movement Party (PMDB). Along with the application of the Cruzado Plan in 1986, the main purpose of which was to tame the exorbitant inflation of the time, the Government changed the law to begin the complete privatization of some existing state-owned enterprises. However, the sale of these corporations was in practice restricted to Brazilian investors.

In 1988, the Government instituted the Federal Program for Denationalization to lower the growing public deficit, thereby fostering the deregulation of the economy and moving public service utilities into the private sector. Later, foreign capital was encouraged to purchase these government-owned corporations.

From 1990, the next President, Fernando Collor de Mello, of the Brazilian Reconstruction Party (PRN), expanded the openness of the Brazilian economy as well the Brazilian Plan for Denationalization.

One of its most important aspects was that foreign capital could carry $40 \%$ of state enterprise common stock or $100 \%$ of the preferred stock.

Interrupted by an impeachment process in December 1992, Collor's term signified the substitution of the national-development model by the liberaldevelopment one. Collor's replacement, Itamar Franco, of the PRN party, slowed down the rate of the privatizations of state-owned corporations.

Through the implementation of a national decree, Franco decided that the State pension funds could no longer be part of the Privatization Program. Besides, he stated that the presidency could limit the use of junk bonds (public debt titles) in the privatization process.

Towards the end of Franco's administration in the last quarter of 1994, import quotas were also reduced for hundreds of products, which negatively affected the balance of trade.

During the two terms of office of President Fernando Henrique Cardoso (1995-2002) of the Brazilian Social Democratic Party (PSDB), there was a continuation of the process of economic openness and as well as of privatization. At that point, the US Government debated setting up a continental free trade zone that would be called the Free Trade Area of the Americas (FTAA), similar to the North American Free Trade Agreement (NAFTA) free trade agreement already established between the United States of America, Canada and Mexico.

The negotiation agenda of the 34 countries in the Americas discussed the need to liberalize the trade of goods and to introduce common legislation for matters related to services, intellectual property, investments, subsidies, safeguards, etc.

However, the negotiations did not include the possibility of a monetary union or the formation of a common central bank - the dollar currency would be progressively adopted as in Ecuador (2000) and El Salvador (2001). Labor and environmental questions did not form the central part of the diplomatic debates.

During that time, the Cardoso Government was dedicated to consolidating its performance in agribusinesses such as orange juice, coffee, meat, sugar, soybeans, etc. as well as in traditional industrial sectors that used an unskilled labor force 
such as textiles and shoe production, bearing in mind the impossibility of competing with the United States, Canadian and even Mexican industry.

Brazil elected to support two basic factors: cheap labor and the vast natural resources of its ores, fertile lands and hydrographic basins.

Despite the rhetoric of extreme liberalization and Brazilian political goodwill, the White House tried to shift the discussion on agricultural products to the World Trade Organization (WTO) to reduce the accessibility of its own market to Brazilian, Argentine and Colombian competitors, amongst others.

The deadline for the establishment of this bloc would be 2005. All the countries in the region would be part of it, except Cuba. Between 2001 and 2003, a 350-page memorandum divided into 10 chapters was produced. However, due to the terrorist attack of September 2001, the priority of US foreign policy would be greatly altered for the next few years.

Even so, the Unites States relaxed its position towards the free trade area of Americas. In its portfolio of investments, the American government defended the end of policies favorable to national enterprises and open up to foreign ones, even if they were compensatory. In practice, the hypothetical FTAA would give egalitarian treatment to all members, since tariffs would be swiftly eliminated.

Thus, giving preferential treatment to internally produced goods could not happen. In addition, any type of restriction related to the sale of specific goods would not exist to Member States, as happens in special export zones in countries like Brazil and China.

The investor would have formal permission to carry out at any time the remittance of profits, repatriation of capital and assets and even receipt of interest and would not be obliged to establish agreements concerning technology transfer. The investors would profit from a higher status when appealing to international arbitration, thereby rising above the legislation of each Member State.

It has been shown that the regional political and economic environment was very unfavorable to the performance of Brazilian business. This environment was incapable of linking up with the equivalent North American one from a financial and technological point of view. In this context Government stimulation policy to specific sectors would be abolished.

Since the beginning of the millennium therefore, Brazil has begun to focus on a presumed agricultural advantage (considered natural from the neoliberal point of view) when offering advantages in its diplomatic negotiations with the United States and the European Union in the areas of intellectual property, foreign investments, and industrial services and goods. (Nogueira Batista, 2003, 267-277).

In January 2003, the Brazilian Labor Party (PT) defeated the ruling Brazilian Social Democratic Party (PSDB), after two four-year terms, from January 1995 to December 2002. When handing the presidential sash to Luís Inácio Lula da Silva, Fernando Henrique Cardoso also left the economy in a fragile state, with high inflation and a basic interest rate of $25 \%$ per year (source: Banco Central do Brasil). 
In order to deal with results of this turbulent heritage the Brazilian administration chose to maintain economic orthodoxy (discipline) running the risk of aggravating the negative effects even more in the short-term. Thus, the establishment of an initial partnership with the financial sector was justified.

One of the greatest symbolic measures of the PT leadership was the decision to appoint Henrique Meireles as Head of the Central Bank. He had previously occupied a high-level post of one of the largest US banks, FleetBoston Financial in the 1990s. After retiring from FleetBoston Financial, he was elected Federal Congressman for the PSDB but he did not even take office in the National Congress because he was asked to direct the Brazilian Central Bank.

With the presence of Henrique Meireles, President Luis Inácio Lula da Silva's administration assured the fulfillment of all commitments established by the preceding government, as shown by its enthusiastic adoption of neoliberalism. For this reason, during the first few months political renovation would not extend to other areas.

Starting from President Luis Inácio Lula da Silva’s very first day in charge, the Brazilian government's posture was to maintain the system of inflation goals set by the National Monetary Council and to preserve a primary surplus with the objective of keeping the due date payment of debt interest to avoid a catastrophic internal domestic debt default. However, the exchange rate of Brazil's currency would continue to fluctuate.

In this government's eight years of administration, inflation was curbed. National economic growth was modest compared to countries such as China and India, despite the world economy profiting from favorable winds until the US crisis in 2008. Between 2002 and 2008, China maintained growth rates ranging from $9 \%$ to $13 \%$ and India from $7.1 \%$ to $9.7 \%$ (with the exception of 2002 when India only managed 3.8\% economic growth) - Superintendência de Estudos Econômicos e Sociais da Bahia, 2010. 


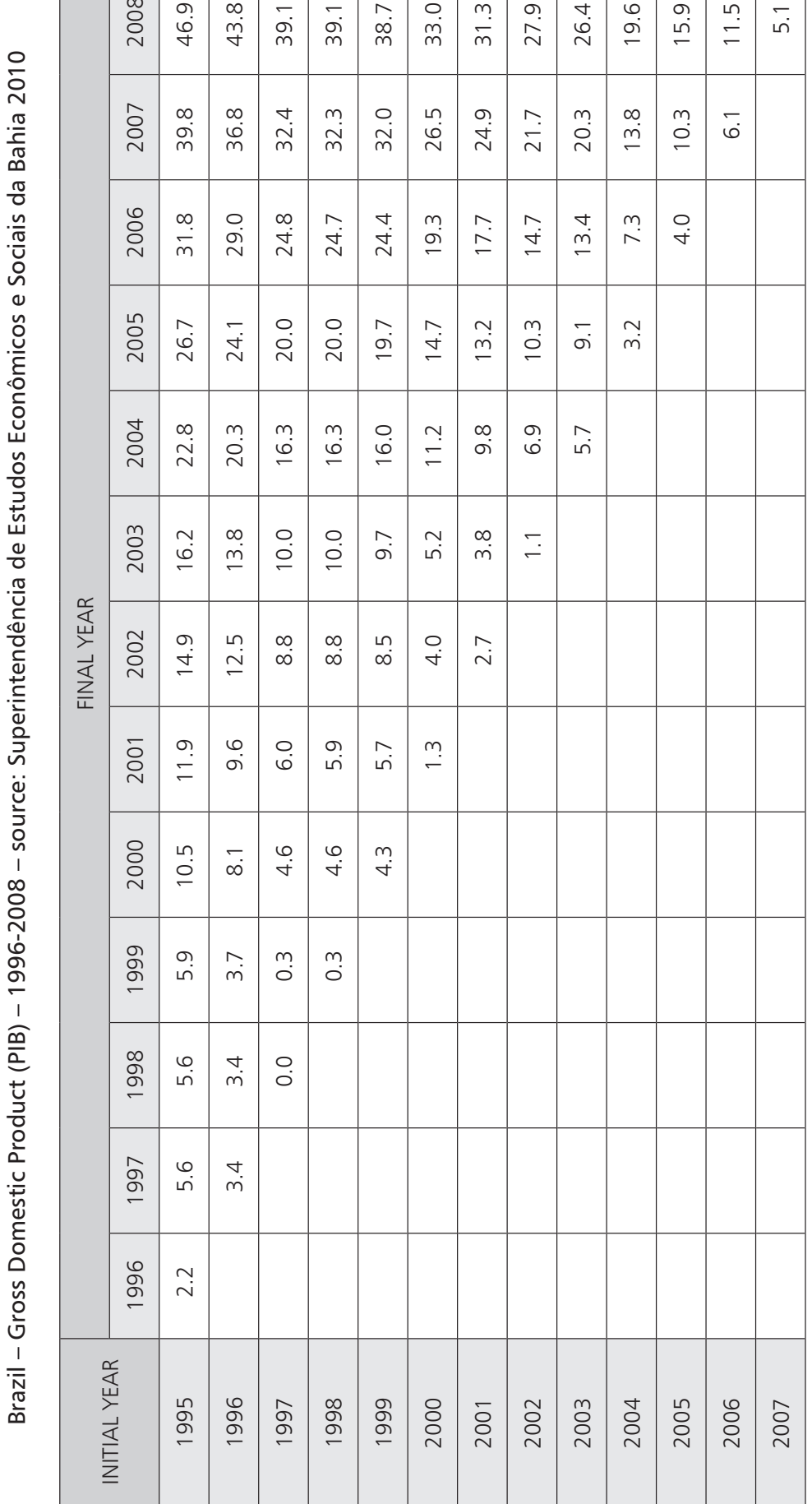




\section{Globalization: the difficulty of internationalizing Brazilian business}

The spread of the globalization process was highlighted after the Cold War with the formation or consolidation of economic blocs, greater circulation of foreign direct investment and regional or world tariff reductions through the General Agreement on Tariffs and Trades (GATT) and later its successor, the World Trade Organization (WTO).

In this new international economic configuration, Brazil did not know how to properly take advantage of the available opportunities, as is seen from the table above. From the beginning of 1997 to the end of 1999, Brazil was able to finance the major part of its current account deficit thanks to the arrival of US\$ 100 billion from FDI. One of the consequences for local industry was to adapt to new patterns of production. Without these new patterns, it would have not been possible to create internal competition (Correa de Lacerda, 2007: 19).

On the other hand, modernization allowed Brazil to plunge into the international market in a more flexible manner, despite its interest rates, which are among the highest on the planet - over $10 \%$ per year.

Basically, there are two prejudicial effects to national business related to such high interest rates: the difficulty of raising capital, thus hampering the decisionmaking process and the expansion of activities, and the over-valuing of the local currency that prevents the increase of exports, especially in the industrial sector.

Well-established traditional sectors of Brazilian industry such as textiles and shoe production have suffered due to the over-valued currency. Even the sectors that were relatively advanced in terms of technology, such as the automobile or chemical industries, have not been able to compete.

In this situation there has been a replacement of internal production by international subsidiaries in the Brazilian territory, by imports. As a consequence, there has been a reduction of FDI and the absorption of technology in different chains of production was disrupted after decades of existence.

From a social point of view, this shift leads to negative consequences, thereby causing an increase of unemployment and reduction of income that can be temporarily cushioned by state interventions through the concession of unemployment benefits and family stipends as part of a government welfare program.

The entrepreneurial sector increasingly complains about the tax quotas applied to export products that consequently reduce competitiveness in various markets, especially those in developing countries.

Because of this, Brazil finds itself in a difficult situation, because in order to achieve continuous development without significant fluctuations it would have to increase its exports in order to gain access to capital goods and eventually to specific raw materials 
At the same time the country has to maintain its primary surplus, which would have a favorable result in the commercial sector, targeting the need to compensate for the deficit in the balance of services - interest on foreign debt, remittance of profits and dividends, and the payment of royalties and licenses.

There is an additional difficulty to the whole scenario: the reiteration of an agro-export model which drives the country's foreign policy in the largest international forums. For this reason we have seen the constitution of the G-20 and Brazil's participation in the Cairns Group. According to Veiga 2005:

It is widely known that Brazil, as a major exporter of agricultural and agro-industrial goods, has adopted an offensive stance in negotiations on the liberalization of trade in agriculture taking place in the WTO, as well as in other negotiating processes (...) in the Free Trade Area of the Americas (FTAA) and EU-Mercosur negotiations, Brazil has presented proposals consistent with those developed in the multilateral arena. However, in the months preceding the WTO Ministerial Conference in Cancún in September 2003, an interesting process of strategy-shifting took place, involving Brazil's stance in negotiations on agriculture (...) Without breaking with the Cairns Group and giving up its pro-trade liberalization stance in agricultural negotiations, Brazil led the setting of an issue-based developing countries' coalition aimed at bargaining jointly during the Ministerial Conference and beyond. This new coalition, the G20, brought together developing countries which traditionally adopted differing even opposed - positions in the agricultural negotiations in the WTO.

According to the data shown below, it is possible to note the growing amount of primary products exported, which has significantly advanced in 10 years, to the detriment of manufactured products.

\begin{tabular}{|l|r|r|r|r|r|r|r|r|r|r|}
\hline & 2000 & 2001 & 2002 & 2003 & 2004 & 2005 & 2006 & 2007 & 2008 & 2009 \\
\hline Special operations & 2.7 & 3.0 & 2.4 & 1.8 & 1.6 & 2.1 & 2.2 & 2.1 & 2.6 & 2.1 \\
Basics & 22.8 & 26.3 & 28.1 & 28.9 & 29.5 & 29.3 & 29.2 & 32.1 & 36.9 & 40.5 \\
Semi-manufactured products & 15.4 & 14.1 & 14.8 & 15.0 & 13.9 & 13.5 & 14.2 & 13.6 & 13.7 & 13.4 \\
Manufactured products & 59.1 & 56.5 & 54.7 & 54.3 & 55.0 & 55.1 & 54.4 & 52.3 & 46.8 & 44.0 \\
\hline
\end{tabular}

Source: Ministério do Desenvolvimento, Indústria e Comércio Exterior 2010. 


\begin{tabular}{|l|c|c|c|c|c|c|}
\hline Sector Period & $\begin{array}{c}\text { High } \\
\text { Technological } \\
\text { Intensity }\end{array}$ & $\begin{array}{c}\text { Low } \\
\text { Technological } \\
\text { Intensity }\end{array}$ & $\begin{array}{c}\text { Primary } \\
\text { Commodities }\end{array}$ & $\begin{array}{c}\text { Work and } \\
\text { Natural } \\
\text { Resources } \\
\text { Intensity }\end{array}$ & $\begin{array}{c}\text { Average } \\
\text { Technology } \\
\text { Intensity }\end{array}$ & $\begin{array}{c}\text { Oil and } \\
\text { Products }\end{array}$ \\
\hline 19991 sem. & 12.4 & 9.4 & 44.8 & 11.7 & 19.7 & 2.0 \\
19992 sem. & 13.7 & 9.2 & 44.0 & 12.1 & 18.5 & 2.4 \\
2000.1 sem. & 15.8 & 9.5 & 41.2 & 12.2 & 18.5 & 2.8 \\
20002 sem. & 17.7 & 9.4 & 38.7 & 12.1 & 18.5 & 3.6 \\
20011 sem. & 17.1 & 8.3 & 38.9 & 12.0 & 18.3 & 5.4 \\
20012 sem. & 16.4 & 8.0 & 40.5 & 11.9 & 17.6 & 5.6 \\
20021 sem. & 16.5 & 8.1 & 39.9 & 12.5 & 17.8 & 5.2 \\
20022 sem. & 14.8 & 8.8 & 40.5 & 12.0 & 17.1 & 6.7 \\
20031 sem. & 12.9 & 9.5 & 41.6 & 11.5 & 17.2 & 7.3 \\
20032 sem. & 11.9 & 9.6 & 41.1 & 11.8 & 18.6 & 7.0 \\
20041 sem. & 11.7 & 9.6 & 41.6 & 11.6 & 18.9 & 6.5 \\
20042 sem. & 11.7 & 11.6 & 40.2 & 11.1 & 19.2 & 6.2 \\
20051 sem. & 11.9 & 12.6 & 39.0 & 10.5 & 20.2 & 5.8 \\
20052 sem. & 12.1 & 10.8 & 39.1 & 9.5 & 20.4 & 8.0 \\
20061 sem. & 12.1 & 9.7 & 38.8 & 9.2 & 20.5 & 9.7 \\
20062 sem. & 12.3 & 10.0 & 39.5 & 8.9 & 19.6 & 9.8 \\
20071 sem. & 12.1 & 10.1 & 40.7 & 8.5 & 18.8 & 9.8 \\
20072 sem. & 11.9 & 9.7 & 41.2 & 8.1 & 18.7 & 10.4 \\
20081 sem. & 11.7 & 9.4 & 41.9 & 7.4 & 18.0 & 11.6 \\
20082 sem. & 11.3 & 10.3 & 43.2 & 6.2 & 16.7 & 12.2 \\
20091 sem. & 11.1 & 9.9 & 47.9 & 5.7 & 15.0 & 10.5 \\
20092 sem. & 11.1 & 7.8 & 51.1 & 5.8 & 13.8 & 10.4 \\
20101 sem. & 10.4 & 7.4 & 49.4 & 5.8 & 14.1 & 13.0 \\
\hline
\end{tabular}

Source:Federação das Indústrias do Estado do Rio de Janeiro 2010

Brazil occupied the 24th place in the classificatory framework of exporting countries in 2009 , being responsible for $1.2 \%$ of the world total. This performance is considered inefficient, notably when compared to other countries such as South Korea at $2.9 \%$, Mexico at $1.8 \%$, Russia at $2.4 \%$, and, China at $9.6 \%$, the latter overtaking Germany (Balança Comercial Brasileira, 2010).

The number of national exporting companies in 2009 was 19,823 - the lowest level since 2004, when Brazilian exporters numbered 21,925. It is worth mentioning that the US crisis of 2008 contributed to this shortfall.

The framework below features the performance distribution of Brazilian firms in the global market before the US setback: 

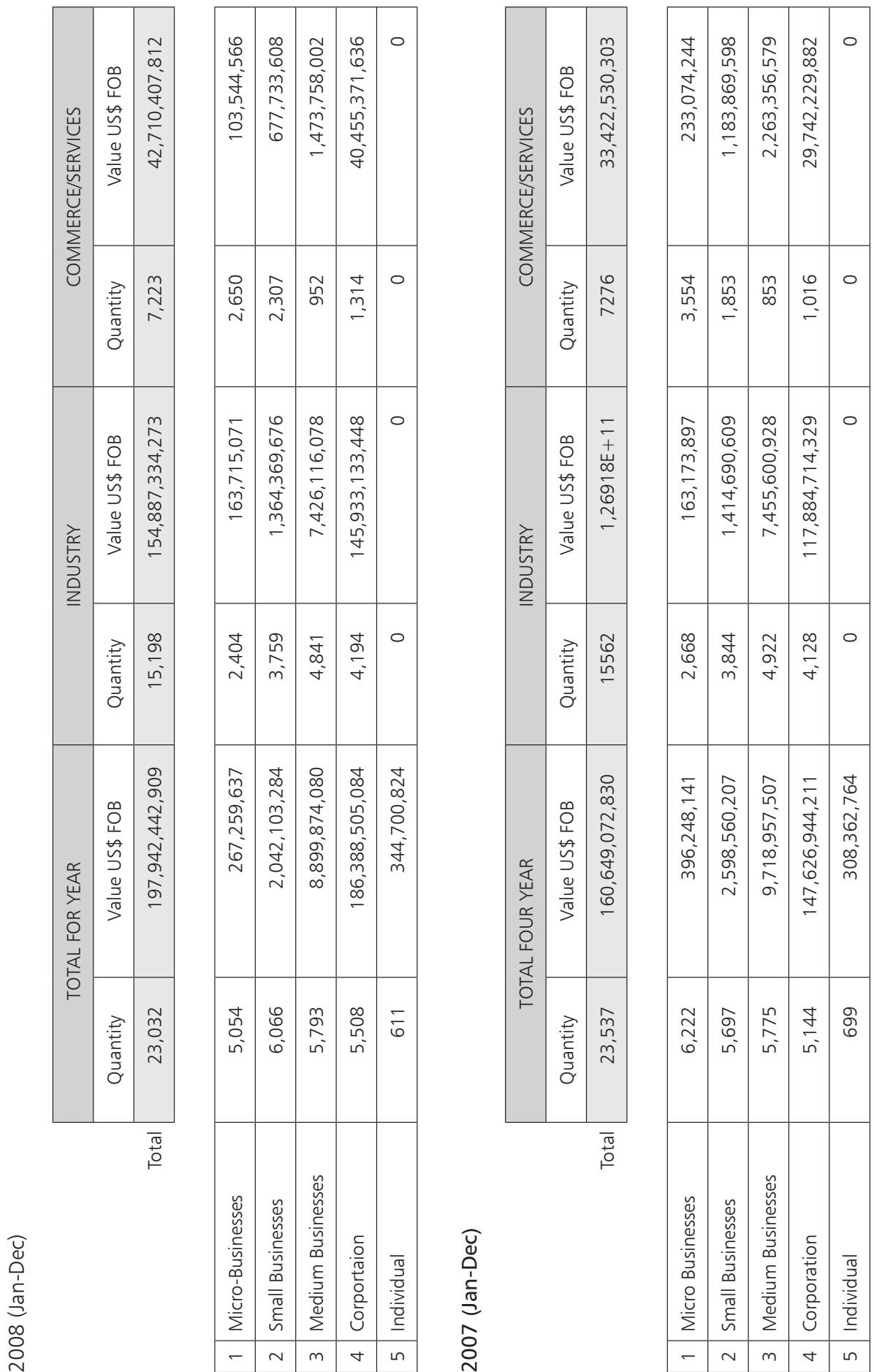

|

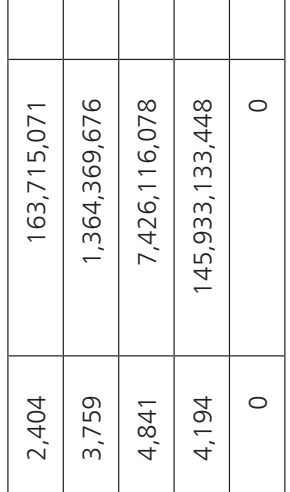

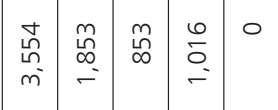
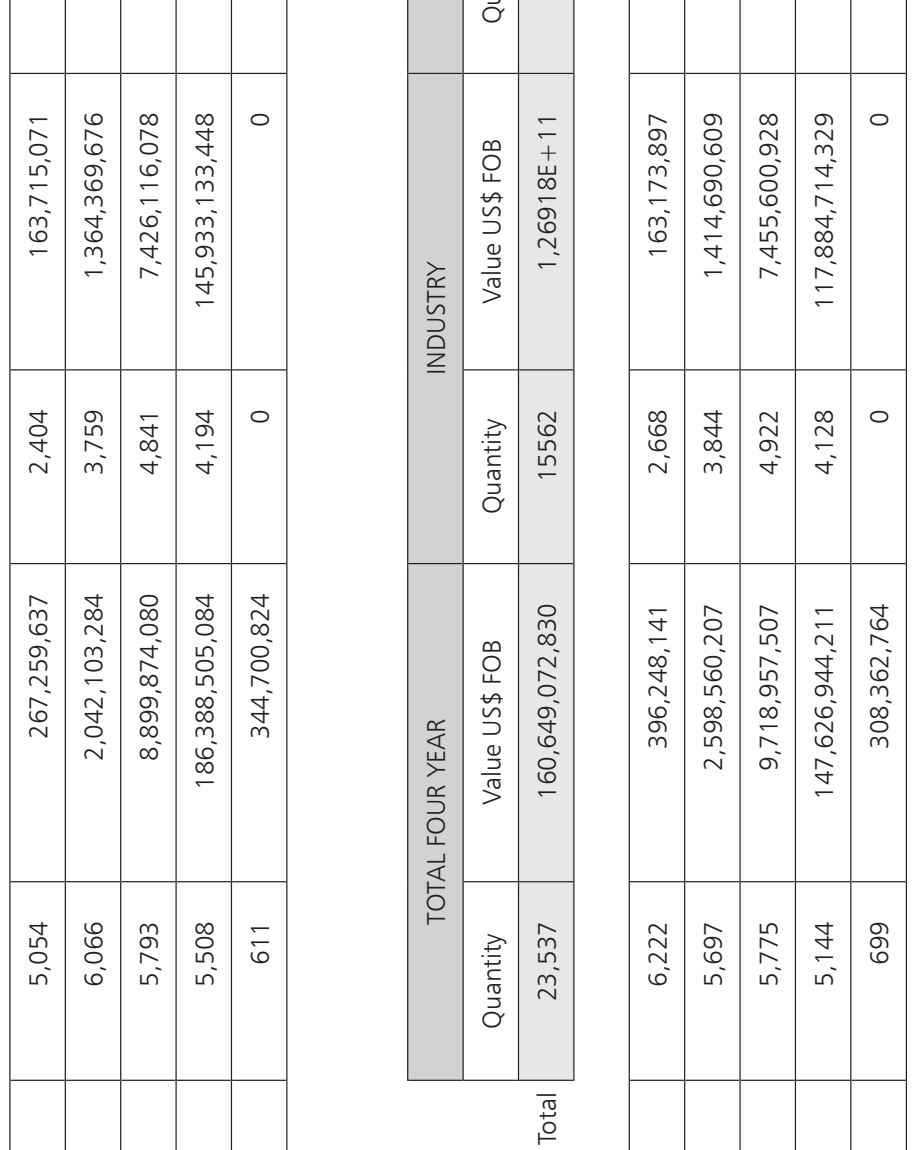

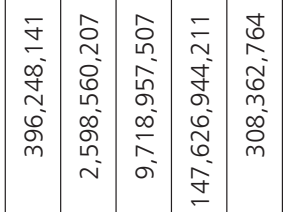
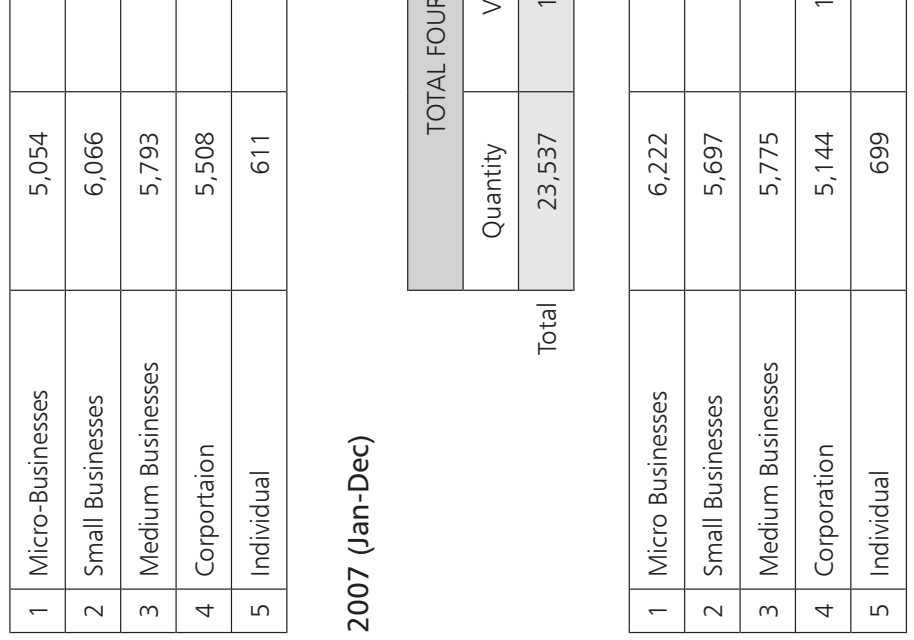
Soybeans and their by-products, oil and fuel, ores, meats, sugar and ethanol, coffee and its by-products, and tobacco and its by-products are examples of the 15 most widely exported products in recent years.

Throughout President Luis Inácio Lula da Silva’s administration the benefit has been observed of the rise of commodity prices due to the growth of Chinese industry. In a certain way, China's growing demand has compensated for the over-valuing of the Brazilian currency, the real, up to 2008.

Brazil reinforced its condition as a commodity producer, both in President Cardoso's administration as well as in that of Luis Inácio Lula da Silva, not allowing consistent reduction of its external vulnerability in order to tie its production to the needs of consumption in other countries, especially the United States and China. 


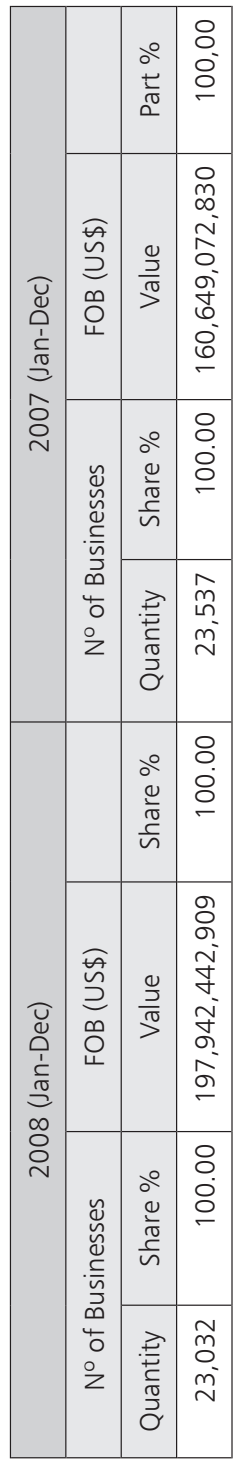

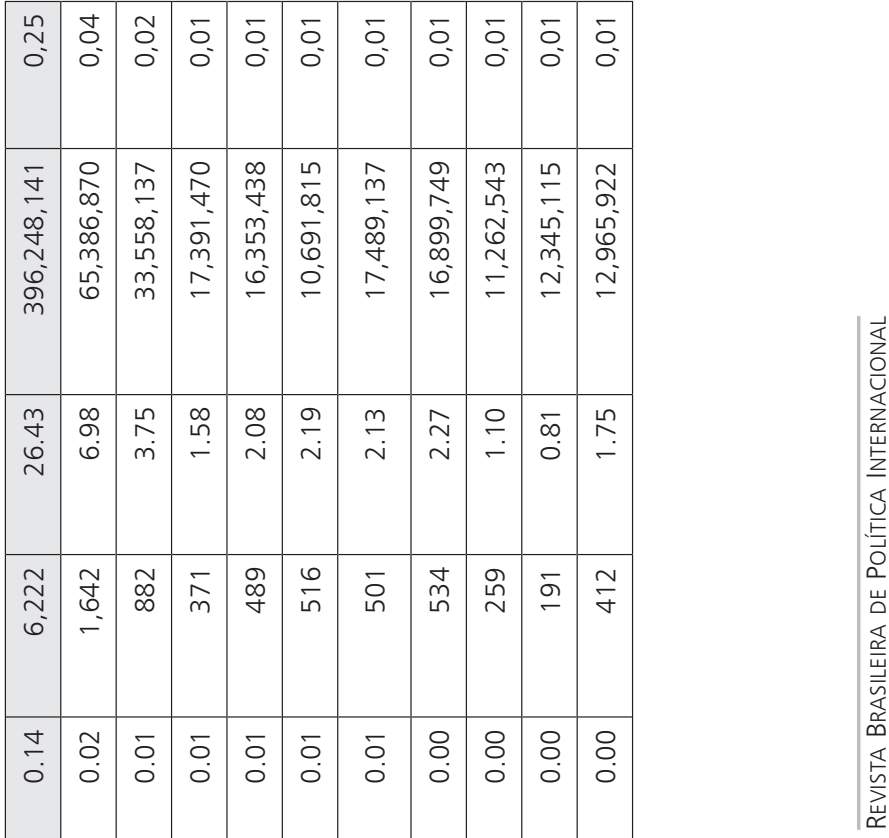

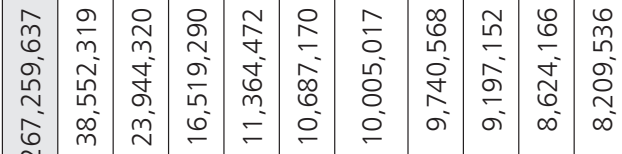

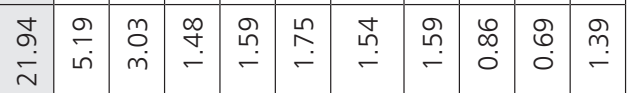

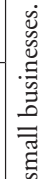

\begin{tabular}{|c|c|c|c|c|c|c|c|c|c|c|}
\hline 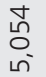 & 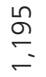 & $\begin{array}{l}\text { જొ } \\
\text { }\end{array}$ & $\underset{m}{\bar{j}}$ & $\begin{array}{l}\stackrel{\bullet}{0} \\
m\end{array}$ & $\stackrel{m}{\circ}$ & 㤐 & $\begin{array}{l}\mathscr{Q} \\
\stackrel{0}{m}\end{array}$ & જ̆ & $\stackrel{\infty}{\stackrel{\infty}{n}}$ & $\underset{\text { m }}{\stackrel{\curvearrowright}{N}}$ \\
\hline 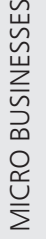 & 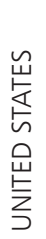 & 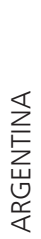 & 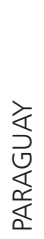 & 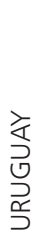 & $\stackrel{\text { 岌 }}{\underset{U}{U}}$ & 㐫 & $\frac{z}{\text { a }}$ & 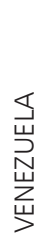 & 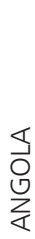 & 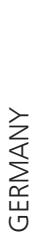 \\
\hline $\begin{array}{l}\frac{\bar{O}}{\overline{\bar{n}}} \\
\text { O }\end{array}$ & $\stackrel{\circ}{\circ}$ & $\stackrel{\circ}{\sim}$ & $\stackrel{\circ}{m}$ & $\stackrel{\circ}{q}$ & in & i & $\stackrel{\circ}{\wedge}$ & $\stackrel{\infty}{\infty}$ & ட் & $\stackrel{\circ}{\circ}$ \\
\hline
\end{tabular}




\begin{tabular}{|c|c|c|c|c|c|}
\hline 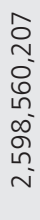 & 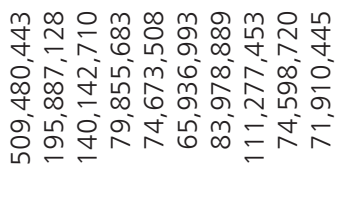 & 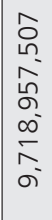 & 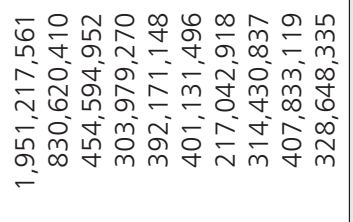 & 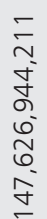 & 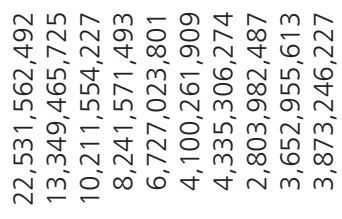 \\
\hline $\begin{array}{l}\stackrel{\circ}{\stackrel{+}{\sim}} \\
\stackrel{+}{\sim}\end{array}$ & 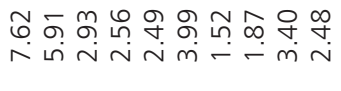 & 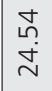 & 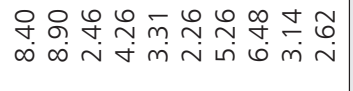 & 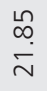 & 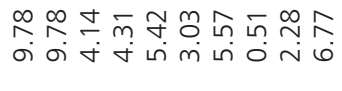 \\
\hline $\begin{array}{l}\hat{\sigma} \\
6 \\
\text { ம் }\end{array}$ & 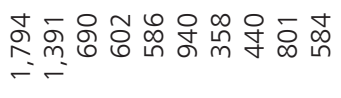 & 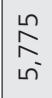 & 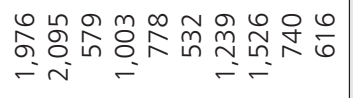 & $\frac{\text { I }}{\stackrel{8}{-}}$ & 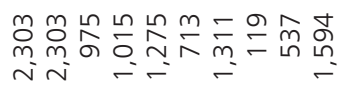 \\
\hline$\stackrel{m}{n} \frac{1}{0}$ & 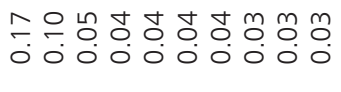 & $\stackrel{\stackrel{\leftrightarrow}{\leftrightarrow}}{\leftrightarrow}$ & 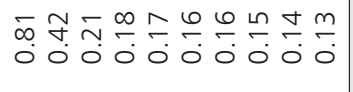 & $\begin{array}{l}\stackrel{6}{\check{J}} \\
\dot{\sigma}\end{array}$ & 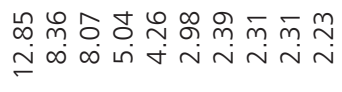 \\
\hline 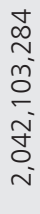 & 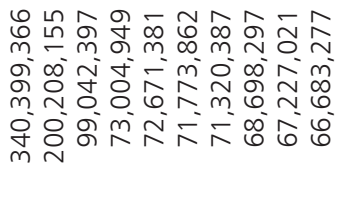 & 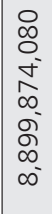 & 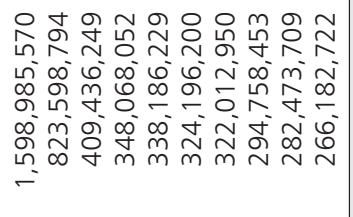 & 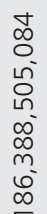 & 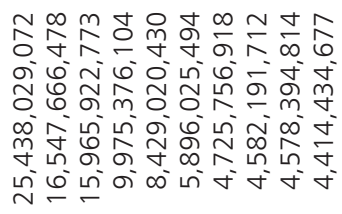 \\
\hline $\begin{array}{l}\stackrel{\nabla}{m} \\
\stackrel{\varphi}{N}\end{array}$ & 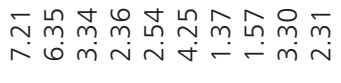 & $\stackrel{\stackrel{\ln }{\sim}}{\stackrel{\min }{\sim}}$ & 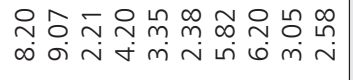 & के & 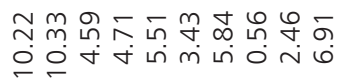 \\
\hline 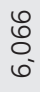 & 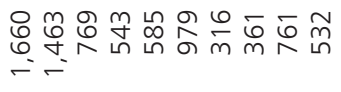 & $\begin{array}{l}m \\
\stackrel{m}{\stackrel{n}{n}} \\
\text { ni }\end{array}$ & 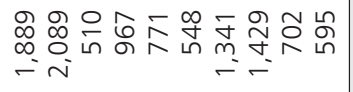 & $\begin{array}{l}\infty \\
\stackrel{\infty}{\complement} \\
\text { மก }\end{array}$ & 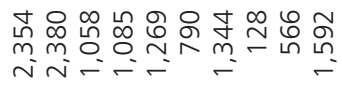 \\
\hline 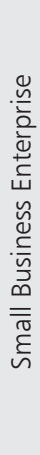 & 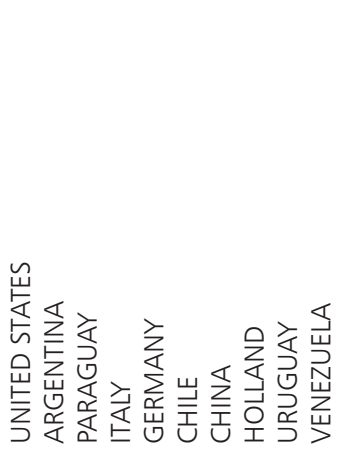 & 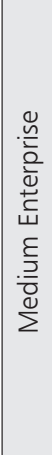 & 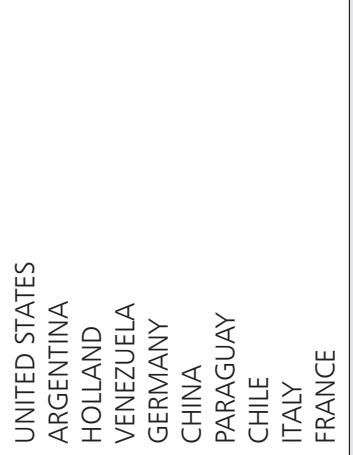 & $\begin{array}{l}\varkappa \\
\frac{n}{0} \\
\frac{0}{0} \\
\overline{0} \\
\frac{0}{0} \\
0\end{array}$ & 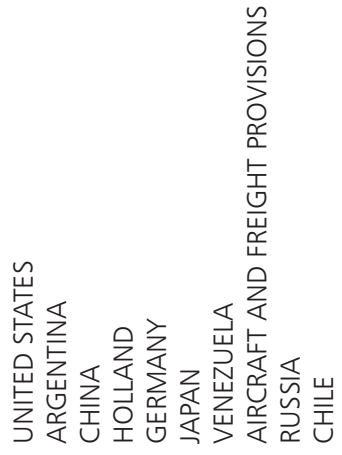 \\
\hline : & 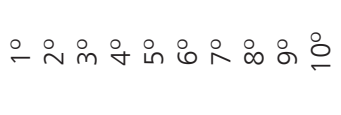 & 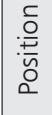 & চ & 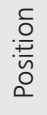 & 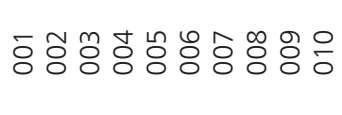 \\
\hline
\end{tabular}


CENTRAL BANK OF BRAZIL

Brazilian Capital Overseas

Tab. 1 - Distribution by Type - 2008

US\$ millions

\begin{tabular}{|l|r|r|}
\hline & \multicolumn{1}{|c|}{2007} & \multicolumn{1}{c|}{2008} \\
\hline TOTAL & 155,176 & 170,397 \\
Foreign Brazilian Direct Investment & 103,923 & 122,140 \\
$\quad$ Direct Investment & 75,376 & 80,226 \\
$\quad$ Intercompany Loans & 28,547 & 41,914 \\
Investiments in Assets & 22,124 & 16,283 \\
$\quad$ Portfolio - stockholders participation & 3,364 & 4,025 \\
$\quad$ BDR & 3,280 & 803 \\
$\quad$ Portfolio - Public Title Debts - Long Term (bonus/bills) & 6,792 & 6,496 \\
$\quad$ Portfolio - Public Title Debts - Short Term (market instruments) & 8,688 & 4,959 \\
Derivatives & 142 & 609 \\
Financing & 99 & 123 \\
Loans & 785 & 658 \\
Deposits & 22,487 & 24,051 \\
Other Investiments & 5,616 & 6,533 \\
Number of declarants & 15,289 & 16,105 \\
\hline
\end{tabular}

Source: Banco Central do Brasil 2009.

In general terms, the capacity of a company to resist problems in the world economy indicates its possible degree of external vulnerability. This capacity is measured in two different ways:

Governments' response options are found in their own economic policies. The greater the number of response options available, the less is their vulnerability. The higher the costs are, the greater is their exposure level, and therefore their vulnerability. The costs of a possible crisis might be seen in the form of a recession or depression.

It should be emphasized that external vulnerability is always present in the situation of all former colonies, which are incapable of overcoming alone the misfortune inherited from their old metropolises (Gonçalves, 1998: 157-8). Thus, one of the greatest economic challenges for Brazil is to overcome this situation.

\section{Internationalization and insertion: the difficulty}

One of the ways to reduce vulnerability would be continuous investment in technological enhancement, infrastructure development, and qualification of labor, thus allowing productivity to rise and guaranteeing the conditions necessary to compete fairly in global markets. 
Since the beginning of the 1990s Brazilian firms have been exposed to the patterns of international competitiveness as customs and non-customs barriers have been gradually eliminated.

During this time, it has been found that many of these firms were not capable of entering the global market insertion because of their technological and managerial backwardness when compared to the similar ones of the North Atlantic axis and China.

Two basic means of renovation would ensure the country's international presence: exports (considering the abundance of raw materials and low labor costs) and foreign direct investments, when profiting from sophisticated technology, highly qualified labor, the country's own financial resources or the capacity of obtaining them, and from a trademark or a special product.

The objective of FDI is to assure the reduction of production costs that can be obtained through easy access to raw materials, infrastructure expansion, political regime, size of consumer market, and the possibility of joint ventures with local businesses.

How can Brazil become more visible in the next 20 years? First, compared to the Unites States, Germany, China, France or Great Britain, Brazil would have a specific advantage more concentrated in access to raw materials than in terms of methods of production and technology generation and more efficient commercialization.

In theory, exports could precede FDI when first verifying the acceptability of a specific product in a market. Its incorporation to the consumption patterns of another country could stimulate its production on a larger scale. However, in practice, Brazil has not achieved any desired success in this sense.

According to the United Nations Conference on Trade and Development (UNCTAD), in 2008 Brazil had only three business among the 100 largest in developing countries in terms of foreign assets (not taking into consideration financial corporations): Vale ${ }^{1}$ (do Rio Doce), was in ninth place in the area of mining and quarrying; Petrobras, was in 16th place in the area of the exploitation, refining and distribution of oil and gas; Gerdau, in 18th place in the sector of metallurgy. None of them is included among the world's 100 biggest companies.

Compared with other countries in Latin America, Mexico had four of the region's 100 largest companies, Cemex, in third place in the mining sector; Argentina, only one: Temium, in metalworking; Venezuela, only one: PDVSA, in the area of petroleum. Mexico was the only country which had one firm among the planet's 100 largest companies.

Brazilian corporations were responsible for receiving 34\% of Latin America's FDI in 2007. The main reason for this is the country's geographical,

1 Since November 2007, the corporation has withdrawn the name 'Vale do Rio Doce' in favor of the new name of 'Vale'. 
cultural and political proximity to the Southern Common Market in South America (MERCOSUR). It is worth mentioning that the foreign policy of President Luis Inácio da Silva’s administration has been much more enthusiastic about a closer relationship with the continent than the preceding administration.

The company with the greatest presence in Latin America was Gerdau, with purchases in Mexico and Venezuela. However, up to 2007, Petrobras was considered the most geographically diversified corporation with branches in almost 21 countries, followed by Gerdau and Vale, both with 18 foreign subsidiaries.

Among the 10 largest Brazilian enterprises throughout the world, Norberto Odebrecht, (construction), Perdigão (food), and Stefanini IT (computer sciences consultancy) were established in 14 countries. Sadia (food) and Camargo Corrêa (construction) were in 13 countries. Randon, (automobiles), and Andrade Gutierrez (construction), were in 12 and 11 countries respectively. (Fundação Dom Cabral, 2008: 11-2).

In 2009, there was a change in this situation: Vale became the major Brazilian conglomerate in international terms, with branches in 33 countries, followed by Petrobras, in 26 countries, and the Banco do Brasil in 23 countries.

Completing the list of the 10 biggest national firms abroad, we have Votorantim, a conglomerate in the capital goods sector, in 21 countries, Weg in the area of automation and Brasil Foods in 20 countries, Odebrecht in 16 countries, Stefanini IT in 10 countries and finally Camargo Corrêa and Gerdau in 14 countries.

Brazilian transnational corporations continue to favor Latin America in terms of investment (Fundação Dom Cabral 2010: 10-1).

\section{Conclusion}

At the beginning of the 1990s, Brazil joined the neoliberal democratic circle, after the direct election of Fernando Collor de Mello. From them on, Brazil's economic insertion in the international context has been gradually based on a process of 'reprimarization', to use the term coined by the economist Reinaldo Gonçalves (Durão, 2007).

Foreign policy has been employed with the objective of reinforcing the country's agro-exporting character, in accordance with the activities of Itamaraty (Ministry of Foreign Affairs) in multilateral forums such as the World Trade Organization (WTO), G-20 and the unsuccessful one of the Free Trade Areas of the America (FTAA).

Internally, the support base of this model has been supplied by the Brazilian Development Bank (BNDES). Through its budget, the government has financed many mergers, with the justification of better stimulating its international participation in specific sectors, almost all of them concentrated in agricultural and extractive activities. 
In practice, the government has centered its strength in the sector of commodities, precisely the one that is most subject to global price variations. The process of 'reprimarization' has negative impacts on the environment because of the possibility of predatory exploitation of natural resources, as well of contributing to generating employment abroad and to the reduction of incountry investments.

On the other hand, the internationalization of businesses aids managerial and technological enhancement through partnerships with foreign corporations.

In addition, this process can help reduce a possible instability in the balance of payments through acquiring the remittance of profits in a strong currency, and dilute research and development costs consequent on dissemination into diverse markets.

An option for the next government, whose change in administration is scheduled to take place in October 2010, is reinforcing the process of internalization of Brazilian firms through the constitution of a specific organization similar to the Overseas Private Investment Corporation (OPIC) established by the US government in 1971.

With the establishment of a specific corporation, a specialized bureaucracy would be instituted, separate from functional body of the Ministry of Foreign Affairs and the Brazilian Development Bank.

An organization aiming at the internationalization of Brazilian enterprises would assist in obtaining credit with more reasonable interest rates and due dates, and contribute to the debate on tax reform - the Brazilian system is based on cumulative taxation, based on the invoice and gross income - and on the need to improve and enlarge the national infrastructure.

Even large corporations fear to apply for international loans because of the volatility of exchange rates these days; the Brazilian real is over-valued when compared to the US dollar.

Thus, Brazil enjoys the necessary conditions to better internationalize its production due to the richness of its natural resources, advanced technology in various segments and a well-qualified labor market. However, the country cannot bring all these elements together so as to broaden its participation in the world market in a long-lasting and consistent way.

\section{Bibliography}

Amann, Edmund, Baer, Werner. 2002. Neoliberalism and Its Consequences in Brazil. Journal of Latin American Studies 4.

Correa de Lacerda, Antônio. 2007. Economia. In. O Brasil no contexto - 1987-2007. Ed. Jaime Pinsky. São Paulo: Contexto.

Durão, Mariana. 2007. O Brasil passa por reprimarização - entrevista com Reinaldo Gonçalves. Correio da Cidadania, September 16. 
Dye, David, Silva, Eduardo de Souza. 1979. A Perspective on the Brazilian State. Latin American Research Review 1.

Evans, Peter. 1977. Multinationals, State-Owned Corporations, and the Transformation of Imperialism: A Brazilian Case Study. Economic Development and Cultural Change 1.

Gonçalves, Reinaldo, Renato Baumann, Otaviano Canuto, and Luis Carlos Prado. 1998. A nova economia internacional. Uma perspectiva brasileira. 2 ed. Rio de Janeiro: Campus.

Gonçalves, Reinaldo, Cristina França, and Idalvo Toscano. 2002. O Brasil nas negociações internacionais de serviços e investimentos. Argumento 9.

Jensen, Nathan. 2003. Democratic Governance and Multinational Corporations: Political Regimes and Inflows of Foreign Direct Investment. International Organization 3.

Nader, Valéria, Brito, Gabriel. 2010. BNDES financia retrocesso do aparelho produtivo, que deve prosseguir no próximo governo - entrevista com Reinaldo Gonçalves. Correio da Cidadania, September 5.

Nogueira Batista, Paulo. 2003. A ALCA e o Brasil. Estudos Avançados 48.

Ramsey, J, L Barakat. 2009. Ranking das Transnacionais Brasileiras 2009: Investimentos no exterior crescem, apesar da crise mundial. Belo Horizonte: Fundação Dom Cabral.

Ramsey, J, L Barakat, L Cruz and S Cretoiu. 2010. Ranking das Transnacionais Brasileiras 2010: Repensando as estratégias globais. Belo Horizonte: Fundação Dom Cabral.

Solingen, Etel. 2001. Mapping Internationalization: Domestic and Regional Impacts. International Studies Quarterly 4.

Strange, Susan. 1992. States, Firms and Diplomacy. International Affairs 1.

Veiga, Pedro Motta. 2005. Brazil and the G20 group of developing countries. In: Managing the Challenges of WTO Participation - 45 Case Studies. Ed. Gallagher, Peter, Patrick Low, and Andrew Stoler. New York: Cambridge University.

\section{Websites}

Banco Central do Brasil. http://www4.bcb.gov.br/Rex/CBE/ftp/CBETab2007_2008.xls (accessed September 25, 2010)

Banco Central do Brasil. Histórico da taxa de juros. http://www.bcb.gov.br/?COPOMJUROS (accessed September 23, 2010)

Federação das Indústrias do Estado do Rio de Janeiro. http://www.firjan.org.br/data/pages/40 28808120E98EC7012122BA8A14346E.htm (accessed September 25, 2010)

Fundação Dom Cabral. Ranking FDC das transnacionais brasileiras - edição 2008. http:// www.kpmg.com.br/publicacoes/RankingTransnacionais_PDF_Final.pdf (accessed September 26, 2010)

Ministério do Desenvolvimento, Indústria e Comércio Exterior. http://www.mdic.gov.br/ arquivos/dwnl_1275505327.pdf (accessed September 25, 2010)

Ministério do Desenvolvimento, Indústria e Comércio Exterior. Balança Comercial Exterior 2009. http://www.desenvolvimento.gov.br/arquivos/dwnl_1275505327.pdf (accessed September 23, 2010) 
Ministério do Desenvolvimento, Indústria e Comércio Exterior. Balança Comercial Exterior 2010 http://www.desenvolvimento.gov.br/arquivos/dwnl_1289220857.pdf (accessed September 23, 2010)

Overseas Private Investment Corporation. http://www.opic.gov/ (accessed September 26, 2010)

Superintendência de Estudos Econômicos e Sociais da Bahia. http://www.sei.ba.gov.br/ images/pib/xls/nacional/pib_nacio_taxa_media_anual.xls (accessed September 23, 2010)

Superintendência de Estudos Econômicos e Sociais da Bahia http://www.sei.ba.gov.br/images/ pib/xls/outros_paises/pib_outrospaises_taxa_mundo.xls (accessed September 23, 2010)

United Nations Conference on Trade and Development. http://www.unctad.org/sections/ dite_dir/docs/wir2010_anxtab27.xls (accessed September 25, 2010)

Received September 1st, 2010 Accepted November 22nd, 2010

\begin{abstract}
The article deals with the internationalization of Brazilian businesses in the current decade. In the 1990s, Brazil embraced economic neoliberalism and promoted a huge opening up of its economy. At that time, Brazilian companies had to adapt rapidly. Twenty years later, the country has reinforced its presence in Latin America and has ensured a better position in the global markets, especially by through agricultural exports.
\end{abstract}

\title{
Resumo
}

O artigo trata da internacionalização das empresas brasileiras na presente década. Nos anos 90, o Brasil adotou o neoliberalismo e promoveu uma ampla abertura da economia. Naquele período, as empresas nacionais tiveram de adaptar-se em pouco tempo. Vinte anos depois, o país reforçou sua presença na América Latina e assegurou uma posição melhor nos mercados globais, especialmente por meio da agroexportação.

Palavras-chave: globalização; empresas brasileiras; política externa

Key words: globalization; Brazilian Enterprises; Brazilian foreign policy 